\title{
An Economic Analysis of Production and Return of Niger Crop Grown in Jashpur District of Chhattisgarh State
}

\author{
Narottam Atree $^{1 *}$, Ajay Kumar Koshta ${ }^{1}$, Mukesh Kumar Parha ${ }^{2}$, \\ Amit Kumar Painkra ${ }^{1}$ and Dayanand Sai Painkra ${ }^{3}$ \\ ${ }^{1}$ Department of Agriculture Economics, ${ }^{2}$ Department of Fruit Science, ${ }^{3}$ Department of \\ Forestry, IGKV, Raipur, (C.G.), India \\ *Corresponding author
}

\section{A B S T R A C T}

\section{Keywords \\ Niger, Production, Gross return, Jashpur}

Article Info

Accepted: 10 September 2020 Available Online: 10 October 2020
The present study is based on An economic analysis of production and return of niger crop grown in Jashpur district of Chhattisgarh state, with the following objective. To work out the cost and returns of niger crop grow in Jashpur district of Chhattisgarh. The average size of holding for niger growers were 0.60 ha. On an average the cost of cultivation of niger was 13485.69 respectively, among different cost items contribution of total labour cost was 34.72 per cent in case of niger. Gross return for in case of niger it was Rs. 16798.41. The input-output ratio for niger 1:1.25. On an average marketable surplus in niger was worked out to be 96.05 percent.

\section{Introduction}

Agriculture plays a vital role in India's economy, more than 54 per cent population of the country engaged in agriculture (Anonymous, 2018), During 2016-17, rice, niger and pigeon-pea production was 110.15 million tonnes, 0.83 lakh tonnes and 4.78 million tonnes, and it has increased by $5.50 \%$, $7.80 \%$ and $86.71 \%$, respectively (Anonymous, 2017b). Paddy (Oryza sativa) is the major staple food crops to large population in the world directly consumed by people more than any other crops. In India, rice occupied 43.19 million hectare area, production 110.15 million tonnes and yield $25.50 \mathrm{q} / \mathrm{ha}$. In India (Anonymous, 2017b)., West Bengal, Uttar Pradesh and Punjab are the three major rice producing states, which contributes more than 35 percent of the total production.

The production of pigeon-pea (Cajanus cajan) in India was 4.78 million tonnes and occupied area 54.01 million ha with average productivity $\quad 8.85 \mathrm{q} / \mathrm{ha}$ in 2016-17 (Anonymous, 2017b).

Niger (Guizotia abyssinica) cultivated for its seeds, which yield a valuable oil used 
for food and as an illuminant, it can also be used as a manure and green manure for increasing soil organic carbon. In Chhattisgarh state, majority of population depends on agriculture. More than 80 percent population of the state is dependent on agriculture and its allied activities (Anonymous 2017a). The state is also known as "Rice Bowl of India".

\section{Materials and Methods}

\section{Sampling Framework}

The detailed sampling framework that has been adopted for accomplishing the objectives of study is given below:

\section{Selection of district}

Chhattisgarh state is consisting of 27 districts. Out of these districts, Jashpur was selected randomly.

\section{Selection of block}

Jashpur district having eight blocks viz., Bagicha, Duldula, Jashpur, Kansabel, Kunkuri, Manora, Farsabahar and Pathalgaon, among the blocks, Pathalgaon and Bagicha were selected purposively as it is the major contributor towards both area and production of major three selected crops (paddy, niger and pigeon-pea), also it has the highest area as compared to other crops.

\section{Selection of village}

From the sampled blocks of Jashpur district, 2 villages were selected from Pathalgaon block which were Jamjhor and Mayurnacha and 3 villages have selected from Bagicha block which namely Mahuadih, Ghughari and Pasiya, the selection of villages was made on the basis of maximum area coverage and production of the major selected crops.
For estimation of cost and returns of major crops, the cost concepts have used that given by the Commission of Agriculture Cost and Prices (CACP) which is given as follows-

\section{Cost of cultivation}

Cost A1: Consist of following 16 items of costs:

1. Value of hired human labour (permanent \& casual)

2. Value of owned bullock labour

3. Value of hired bullock labour

4. Value of hired machinery

5. Value of owned machinery

6. Value of fertilizers

7. Value of manure (produced on farm and purchased)

8. Value of seed (both farm-produced and purchased)

9. Value of insecticides and fungicides.

10. Irrigation charges (both of the owned \& owned and hired tube wells, pumping sets, etc.)

11. Canal-water charges

12. Land revenue, cesses and other taxes

13. Depreciation on farm implements (both bullock drawn \& worked with human labour)

14. Depreciation on farm building, farm machinery.

15. Interest on the working capital.

16. Miscellaneous expenses (wages of artisans, and repairs to small farm implements).

Cost $\mathrm{A} 2=$ Cost $\mathrm{A} 1+$ Rent paid for Leased in Land.

Cost $\mathrm{B} 1=$ Cost $\mathrm{A} 1+$ Interest on value of Owned fixed Capital assets (excluding land)

Cost $\mathrm{B} 2=$ Cost $\mathrm{B} 1+$ rental value of owned land and rent paid for leased in land.

Cost $\mathrm{C} 1=$ Cost $\mathrm{B} 1+$ Imputed value of family labour. 
Cost $\mathrm{C} 2=$ Cost $\mathrm{B} 2+$ Imputed value of family labour.

Cost $\mathrm{C} 3=$ Cost $\mathrm{C} 2+10 \%$ of managerial charges at Cost $\mathrm{C} 2$.

Income over cost $\mathrm{A} 1=$ Gross income - Cost A1

Income over cost A2 = Gross income CostA2

Income over cost $\mathrm{B} 2=$ Gross income - Cost B1

Income over cost $\mathrm{B} 2=$ Gross income - Cost B2

Income over cost $\mathrm{C} 1=$ Gross income CostC1

Income over cost $\mathrm{C} 2=$ Gross income - Cost C

Income over cost $\mathrm{C} 3=$ Gross income - Cost C

\section{Variable cost}

This includes all the cash expenses made during the period of crop growth stages namely, labour wages, bullock pair, wages, seed, plant protection chemicals, manures and fertilizers, interest on working capital etc. Which is calculated in Rs./ha.

\section{Fixed Cost}

This includes, Depreciation, land revenue and Interest on fixed capital and it is calculated in Rs./ha

\section{Estimation of income}

These include detailed analysis of cost and returns of the crop, such as gross income, net income, and input-output ratio.

\section{(a) Gross income}

It is the sum of all earnings before any deducing of taxes.

\section{(b) Net income}

It is the difference between total receipts and total expenses. It includes the farm manager's expenses and interest on capital invested in the business. It was calculated as:

Net income $=$ Gross income - Total expenses

\section{(c) Input-output ratio}

It can be expressed as the ratio of output to input. The ratio was calculated as:-

Input-output ratio $=\mathrm{O} / \mathrm{I}$

Where, $\mathrm{I}=$ Total input

$\mathrm{O}=$ Total output

\section{Results and Discussion}

\section{Cost of cultivation of niger}

The cost of inputs used for niger cultivation under sample farms was estimated in Rs. per hectare and presented in table 1 . Table reveals that overall cost of input used for niger was found to be Rs. per ha. 8799.90 (65.25 per cent), which varies from Rs8165.37 (63.95 per cent), 8572.95 (64.05 per cent), 8878.45(65.42 per cent) and 10692.41 (70.07 per cent) per ha at marginal, small, medium and large farms respectively.

The most costly input for cultivation of niger was human labour which was found to be Rs 4682.23 per ha (34.72). The overall share of human labour cost was noticed to be Rs4682.23 per ha. and 4452.47, 4663.36, 4725.88 and 5177.43 Rs. per ha. at marginal, small, medium and large farms respectively. 
Bullock Labour was the next input in niger cultivation which accounted 14.53 per cent cost followed by machine charge 5.33 per cent. It was observed that the niger cultivators had not applied the recommended dose of fertilizers there by resulting in reduced yield of niger. In view of this, it is imperative to educate and create awareness about the proper application of inputs in order to increase production and productivity of niger in the study area.

Table.1 Input wise cost of cultivation of niger

\begin{tabular}{|c|c|c|c|c|c|c|}
\hline S.N. & Particulars & Marginal & Small & Medium & Large & Over All (Rs./ha) \\
\hline A. & Variable cost & & & & & \\
\hline \multirow[t]{7}{*}{1.} & Human labour & & & & & \\
\hline & \multirow{2}{*}{ Family labour } & 3424.49 & 3367.94 & 2317.24 & 2246.23 & 2930.62 \\
\hline & & $(26.82)$ & $(25.16)$ & $(17.08)$ & $(14.72)$ & $(21.73)$ \\
\hline & \multirow[t]{2}{*}{ Hired labour } & 1027.98 & 1295.42 & 2408.64 & 2931.20 & 1751.61 \\
\hline & & $(8.05)$ & $(9.68)$ & $(17.75)$ & (19.21) & (12.99) \\
\hline & \multirow[t]{2}{*}{ Total human labour } & 4452.47 & 4663.36 & 4725.88 & 5177.43 & 4682.23 \\
\hline & & $(34.87)$ & $(34.84)$ & $(34.82)$ & (33.93) & $(34.72)$ \\
\hline \multirow[t]{7}{*}{2.} & \multicolumn{6}{|l|}{ bullock labour } \\
\hline & \multirow[t]{2}{*}{ Owned } & 1936.31 & 1596.24 & 61.30 & 724.11 & 1123.77 \\
\hline & & $(15.16)$ & (11.93) & $(0.45)$ & $(4.75)$ & $(8.33)$ \\
\hline & \multirow[t]{2}{*}{ Hired } & 528.79 & 1041.57 & 1266.38 & 0.00 & 836.47 \\
\hline & & $(4.14)$ & $(7.78)$ & $(9.33)$ & $(0.00)$ & $(6.20)$ \\
\hline & \multirow[t]{2}{*}{ Total bullock labour } & 2465.1 & 2637.81 & 1327.68 & 724.11 & 1960.24 \\
\hline & & $(19.30)$ & (19.71) & $(9.78)$ & $(4.75)$ & $(14.53)$ \\
\hline \multirow[t]{8}{*}{3.} & \multirow[t]{2}{*}{ machine charge } & & & 1421.35 & 2398.59 & 718.92 \\
\hline & & $(0.00)$ & $(0.00)$ & $(10.47)$ & $(15.72)$ & $(5.33)$ \\
\hline & \multirow[t]{2}{*}{ 4. seed cost } & 624.37 & 648.92 & 712.55 & 850.83 & 685.22 \\
\hline & & (4.89) & $(4.85)$ & $(5.25)$ & $(5.58)$ & $(5.08)$ \\
\hline & \multirow{2}{*}{$\begin{array}{l}\text { 5. Manure \& Fertilizer } \\
\text { cost }\end{array}$} & 309.38 & 293.13 & 349.52 & 1130.20 & 414.83 \\
\hline & & $(2.42)$ & $(2.19)$ & $(2.58)$ & $(7.41)$ & $(3.08)$ \\
\hline & \multirow{2}{*}{$\begin{array}{l}\text { 6. Interest on working } \\
\text { capital }\end{array}$} & 314.05 & 329.73 & 341.48 & 411.25 & 338.46 \\
\hline & & $(2.46)$ & $(2.46)$ & $(2.52)$ & $(2.70)$ & $(2.51)$ \\
\hline \multirow{2}{*}{\multicolumn{2}{|c|}{ Sub total }} & 8165.37 & 8572.95 & 8878.45 & 10692.41 & 8799.90 \\
\hline & & (63.95) & $(64.05)$ & $(65.42)$ & $(70.07)$ & $(65.25)$ \\
\hline B. & Fixed cost & & & & & \\
\hline \multirow[t]{2}{*}{1.} & \multirow{2}{*}{ Land revenue } & 12.00 & 12.00 & 12.00 & 12.00 & 12.00 \\
\hline & & $(0.09)$ & $(0.09)$ & $(0.09)$ & $(0.08)$ & $(0.09)$ \\
\hline \multirow[t]{2}{*}{2.} & \multirow{2}{*}{$\begin{array}{l}\text { Depreciation } \\
\text { implements }\end{array}$} & 333.33 & 522.73 & 413.79 & 300.00 & 407.80 \\
\hline & & $(2.61)$ & (3.91) & $(3.05)$ & $(1.97)$ & $(3.02)$ \\
\hline \multirow[t]{2}{*}{3.} & \multirow{2}{*}{$\begin{array}{l}\text { Rental value of owned } \\
\text { land }\end{array}$} & 3840.00 & 3840.00 & 3840.00 & 3840.00 & 3840.00 \\
\hline & & (30.07) & (28.69) & (28.30) & (25.16) & (28.47) \\
\hline \multirow[t]{2}{*}{4.} & \multirow[t]{2}{*}{ Interest on fixed capital } & 418.53 & 437.47 & 426.58 & 415.20 & 425.98 \\
\hline & & (3.28) & $(3.27)$ & (3.14) & $(2.72)$ & $(3.16)$ \\
\hline \multirow{2}{*}{\multicolumn{2}{|c|}{ Sub total }} & 4603.86 & 4812.20 & 4692.37 & 4567.20 & 4685.78 \\
\hline & & $(36.05)$ & (35.95) & $(34.58)$ & (29.93) & $(34.75)$ \\
\hline \multirow{2}{*}{\multicolumn{2}{|c|}{ Total $(A+B)$}} & 12769.23 & 13385.15 & 13570.82 & 15259.61 & 13485.69 \\
\hline & & $(100.00)$ & $(100.00)$ & $(100.00)$ & $(100.00)$ & $(100.00)$ \\
\hline
\end{tabular}


Int.J.Curr.Microbiol.App.Sci (2020) 9(10): 1176-1182

Table.2 Break-up of cost, cost concept wise cost in niger at the sample farm

\begin{tabular}{|c|c|c|c|c|c|c|}
\hline Sn & Costs/Category & Marginal & Small & Medium & Large & Overall (Rs/ha) \\
\hline \multicolumn{7}{|c|}{ Break up cost } \\
\hline 1. & Cost A1(All actual expenses) & 5086.21 & 3101.93 & 5659.33 & 8034.08 & 4328.84 \\
\hline 2. & $\begin{array}{l}\text { Cost } A 2=\text { Cost } A 1+\text { Rent paid for } \\
\text { leased in land }\end{array}$ & 5086.21 & 3101.93 & 5659.33 & 8034.08 & 4328.84 \\
\hline 3. & $\begin{array}{l}\text { Cost } \mathrm{B}=\mathrm{A} 1+\text { Rental value of } \\
\text { owned land }+ \text { interest on fixed } \\
\text { capital }\end{array}$ & 9344.74 & 7379.41 & 9925.91 & 12289.28 & 8594.82 \\
\hline 4. & $\begin{array}{l}\text { Cost } \mathrm{B} 1=\text { Cost } \mathrm{A} 1+\text { Interest on } \\
\text { value of owned fixed capital }\end{array}$ & 5504.74 & 3539.41 & 6085.91 & 8449.28 & 4754.82 \\
\hline 5. & $\begin{array}{l}\text { Cost B2=Cost B1+Rental value of } \\
\text { owned land \& Rent paid for leased } \\
\text { in Land }\end{array}$ & 8926.21 & 6941.93 & 9499.33 & 11874.08 & 8168.84 \\
\hline 6. & Cost $\mathrm{C}=$ cost $\mathrm{B}+$ family labour & 12769.23 & 10747.34 & 12243.15 & 14535.51 & 11525.44 \\
\hline 7. & $\begin{array}{l}\text { Cost } \mathrm{C} 1=\text { Cost } \mathrm{B} 1+\text { imputed value } \\
\text { of family labour }\end{array}$ & 8929.23 & 6907.34 & 8403.15 & 10695.51 & 7685.44 \\
\hline 8. & $\begin{array}{l}\text { Cost } \mathrm{C} 2=\text { Cost } \mathrm{B} 2+\text { imputed value } \\
\text { of family labor }\end{array}$ & 12350.70 & 10309.87 & 11816.57 & 14120.31 & 11099.46 \\
\hline 9. & $\begin{array}{l}\text { Cost } \mathrm{C} 3=\text { Cost } \mathrm{C} 2+10 \% \text { of Cost } \\
\mathrm{C} 2 \text { on account of managerial } \\
\text { function performed by farmer }\end{array}$ & 13585.77 & 11340.86 & 12998.23 & 15532.34 & 12209.41 \\
\hline
\end{tabular}

Table.3 Yield, cost and return of niger of the sample farm

\begin{tabular}{|r|l|l|l|l|l|l|}
\hline S/No. & \multicolumn{1}{|c|}{ Particular } & \multicolumn{1}{|c|}{ Marginal } & \multicolumn{1}{|c|}{ Small } & \multicolumn{1}{|c|}{ Medium } & \multicolumn{1}{|c|}{ Large } & \multicolumn{1}{c|}{ Overall (Rs./ha.) } \\
\hline 1. 1. & Yield of main product(q) & 3.64 & 3.76 & 3.7 & 3.98 & 3.73298 \\
\hline 2. 3. & Price main product (Rs./q) & 4500.00 & 4500.00 & 4500.00 & 4500.00 & 4500.00 \\
\hline 3. 4. & Cost of cultivation & 12769.23 & 13385.15 & 13570.82 & 15259.61 & 13485.69 \\
\hline 4. 5. & cost of production/qt & 3508.03 & 3559.88 & 3667.79 & 3834.07 & 3610.33 \\
\hline 5. 6. & Gross return & 16380.00 & 16920.00 & 16650.00 & 17910.00 & 16798.41 \\
\hline 6. 7 & net return & 3610.77 & 3534.85 & 3079.18 & 2650.39 & 3312.725 \\
\hline Input output ratio & 1.28 & 1.26 & 1.23 & 1.17 & 1.247426 \\
\hline
\end{tabular}

Table.4 Income of niger over different cost at sampled farms (Rs./ha.)

\begin{tabular}{|c|l|l|l|l|l|l|}
\hline S.n & Income over different cost & Marginal & Small & Medium & Large & Overall \\
\hline 1 Income over Cost A1 & 11293.79 & 13818.07 & 10990.67 & 9875.92 & 13581.16 \\
\hline 2 Income over Cost A2 & 11293.79 & 13818.07 & 10990.67 & 9875.92 & 13581.16 \\
\hline 3 Income over Cost B & 7035.26 & 9540.59 & 6724.09 & 5620.72 & 9315.18 \\
\hline $\mathbf{4}$ Income over Cost B1 & 10875.26 & 13380.59 & 10564.09 & 9460.72 & 13155.18 \\
\hline $\mathbf{5}$ Income over Cost B2 & 7453.79 & 9978.07 & 7150.67 & 6035.92 & 9741.16 \\
\hline 6 Income over Cost C & 3610.77 & 6172.66 & 4406.85 & 3374.49 & 6384.56 \\
\hline 7 Income over Cost C1 & 7450.77 & 10012.66 & 8246.85 & 7214.49 & 10224.56 \\
\hline 8 Income over Cost C2 & 4029.30 & 6610.13 & 4833.43 & 3789.69 & 6810.54 \\
\hline 9 Income over Cost C3 & 2794.23 & 5579.14 & 3651.77 & 2377.66 & 5700.59 \\
\hline
\end{tabular}


Cost of cultivation of niger on the basis of cost concept at sampled households

The cost of cultivation has also be computed on the basis of cost concept used by the Commission of Agriculture Cost and Price (CACP) presented in Table 2. It reveals that estimated cost $A_{1}$ was maximum at large farm and found to be Rs 8034.08 per ha fallowed by medium (Rs 5659.33 per ha), marginal (5086.21) and small (Rs 3101.93 per ha) respectively. Overall cost $A_{1}$, was estimated to be Rs 4328.84 per ha. As already being noted that cost $A_{1}$ actual expenses or variable cost in niger cultivation. Cost $\mathrm{A}_{2}$ include the rent paid for leased in land which was found to be same as Cost $A_{1}$ because the sample farmer haven't taken any land in leased. Cost $\mathrm{C}_{3}$ was noted noticed to be Rs. 150563.88 which include 10 per cent of Cost $\mathrm{C}_{2}$ as accounted of managerial function perform by farmers and same was noted to be increase of 48.60 over cost $A_{1}$.

Yield, cost and return of niger at the sampled farms

The above table 3 represents the Yield, cost and return of niger. The average yield from the sample farms was maximum in large 3.98 $\mathrm{q} /$ ha followed by small $3.76 \mathrm{q} / \mathrm{ha}$, medium $3.70 \mathrm{q} / \mathrm{ha}$, and marginal farms $3.64 \mathrm{q} / \mathrm{ha}$. The average price was 4500 Rs. for all land holdings. The maximum cost of cultivation occurred in large farms Rs. 15259.61, followed by medium farms Rs. 13570.82, small farms Rs. 13385.15 and marginal farms Rs. 12769.23 respectively, which resulted due to farm size and amounts of input expenditure.

As far as cost of production per quintal is concerned, it was minimum in marginal farms Rs. 3508.03, followed by small farms Rs. 3559.88, medium Rs. 3667.79 and maximum in large farms Rs. 3834.07 per quintal. This resulted because of large farm size could more expend in input applications, and use of outside labors rather than family labors, which ultimately increased cost of production.

Although, gross return was highest in large farms Rs. 17910.00 followed by small Rs. 16920.00, medium Rs. 16650.00 and marginal farms with Rs. 16380.00, respectively. Still, net returns was maximum in marginal farms Rs. 3610.77 followed by small farms Rs. 3534.85, medium farms Rs. 3079.18 and minimum in large farms Rs. 2650.39

The input output ratio is maximum for small farms, 1:2.91, followed by medium farms, $1: 2.86$ and minimum in large farms with ratio of 1:2.82. Increased return from input in small farms is maximum due to increased productivity aroused due to minimum cost incurred. Also, in small farms, family labors are more active and do farm operations more efficiently, whereas in medium and large farms contribution of family labors decreases with increasing farm size and more labors are to be employed from outside and paid.

\section{Income over different cost at sampled farms}

Income over different cost was also calculated for the sample farms (Table 4). Income over cost A1 was maximum in small farms (Rs. 13818.07) followed by marginal farms (Rs. 11293.79), medium (Rs. 10990.67) and minimum in large farms (Rs. 9875.92). Income over cost A2 was also same as income over cost A1 following similar trend. Income over Cost B1 was Rs.10875.26, Rs. 13380.59, Rs.10564.09 and Rs. 9460.72 for marginal, small, medium and large farms respectively.

Income over Cost B2 was Rs.7453.79, Rs. 9978.07, Rs.7150.67 and Rs. 6035.92 for marginal, small, medium and large farms 
respectively. Income over Cost $\mathrm{C} 1$ was maximum in small farms followed by medium and marginal and minimum in large farms with Rs.10012.66, Rs.8246.85, 7450.77 and Rs. 7214.49 respectively. Income over Cost C2 was maximum in small farms Rs.6610.13, followed by medium and marginal farms Rs.4833.43 and 4029.30 and minimum in large farms Rs.3789.69. Income over Cost C3 also follows similar trend with Rs.5579.14, Rs. 3651.77, Rs. 2794.23and Rs. 2377.66 in small, medium marginal and large farms respectively. The overall income over Cost A1, A2, B1, B2, C1, C2 and C3 was Rs. 13581.16, Rs. 13581.16, Rs. 13155.18, Rs. 9741.16, Rs. 10224.56, Rs. 6810.54, Rs. 6810.54 and Rs. 5700.59 respectively.

In conclusion

Total area under niger cultivation of Chhattisgarh state during 2017-18 were observed as, 63245 ha and and production was 25743 metric tones.

The overall input-output ratio of rice, niger and pigeon-was found 1.86, 1.17 and 1.75.
Most costly human input for cultivation of niger was human labour at cost Rs.4682.23 per ha (34.72 percent).

The average yield of niger from the sample farms was maximum in large $3.98 \mathrm{q} / \mathrm{ha}$.

\section{References}

Anonymous. 2018. Annual Report 2017-18. Department of Agriculture, Cooperation \& Farmers Welfare Ministry of Agriculture \& Farmers Welfare Government of India.

Anonymous. 2017b. Pocket Book of Agricultural Statistics 2017. Government of India, Ministry of Agriculture \& Farmers Welfare, Department of Agriculture, Cooperation \& Farmers Welfare Directorate of Economics \& Statistics New Delhi, p.21-27.

Anonymous. 2017a. Economic Survey 2017-

18, Directorate of Economic and Statistics, Chhattisgarh, Raipur.

https://www.indiatoday.in

http://vikaspedia.in

\section{How to cite this article:}

Narottam Atree, Ajay Kumar Koshta, Mukesh Kumar Parha, Amit Kumar Painkra and Dayanand Sai Painkra. 2020. An Economic Analysis of Production and Return of Niger Crop Grown in Jashpur District of Chhattisgarh State. Int.J.Curr.Microbiol.App.Sci. 9(10): 11761182. doi: https://doi.org/10.20546/ijcmas.2020.910.141 